\title{
ANALISIS SEKTOR UNGGULAN DALAM PENYERAPAN TENAGA KERJA DI KABUPATEN MINAHASA SELATAN
}

\author{
Andrew Lahama \\ Leonardus R. Rengkung \\ Eyverson Ruauw
}

\begin{abstract}
This study aims to analyze the leading sectors in the absorption of labor and to know the contribution of the leading sector in the absorption of labor in south Minahasa Regency. The research was conducted for two months starting from months January to months Ferbruay 2018. The date used in this study is secondary date obtained from the Central Bureau of Statistics (BPS) South Minahasa Regency. The date is processed using location quotient analysis (LQ) and the date is presented in table and described descriptively. The research results show that the leading sectors in the absorption of labor in South Minahasa Regency are the processing industry sector, electricity, gas and drinking water sector; and agriculture sector. The first sector with the highest average $L Q$ is the processing industry sector with an average value of $L Q$ 2.22. The second seeded sector is the electricity, gas and dringking water sector with an average $L Q$ of 1.50 and the third leading sector is the agricultural sector with an average LQ of 1.23. The processing industry sector, electricity, gas and dringking water sector and agriculture sector become the leading one because it has $L Q$ value more dominant in the absorption of manpower that the sector the same in north sulawesi province. er* $^{*}$.
\end{abstract}

Keywords: analysis, superior sector, employment absorption, South Minahasa Regency.

\begin{abstract}
ABSTRAK
Penelitian ini bertujuan untuk menganalisis sektor-sektor unggulan dalam penyerapan tenaga kerja dan untuk mengetahui kontribusi sektor unggulan dalam penyerapan tenaga kerja di Kabupaten Minahasa Selatan. Penelitian ini dilakukan selama dua bulan mulai dari bulan Januari hingga bulan Ferbruay 2018. Data yang digunakan dalam penelitian ini adalah data sekunder yang diperoleh dari Badan Pusat Statistik (BPS) Kabupaten Minahasa Selatan. Data tersebut diproses menggunakan analisis location quotient (LQ) dan data disajikan dalam tabel dan dideskripsikan secara deskriptif. Hasil penelitian menunjukkan bahwa sektor-sektor unggulan dalam penyerapan tenaga kerja di Kabupaten Minahasa Selatan adalah sektor industri pengolahan, listrik, gas dan air minum; dan sektor pertanian. Sektor pertama dengan rata-rata LQ tertinggi adalah sektor industri pengolahan dengan nilai rata-rata LQ 2,22. Sektor unggulan kedua adalah sektor listrik, gas, dan air minum dengan rata-rata LQ 1,50 dan sektor unggulan ketiga adalah sektor pertanian dengan rata-rata LQ 1,23. Sektor industri pengolahan, listrik, gas dan sektor air minum dan sektor pertanian menjadi yang terdepan karena memiliki nilai LQ yang lebih dominan dalam penyerapan tenaga kerja yang sektornya sama di provinsi sulawesi utara. $*^{*}{ }^{*}$.
\end{abstract}

Kata kunci: analisis, sektor unggulan, penyerapan tenaga kerja, Kabupaten Minahasa Selatan.

Agrisosioekonomi:

Jurnal Transdisiplin Pertanian (Budidaya Tanaman, Perkebunan, Kehutanan, Peternakan, Perikanan), Sosial dan Ekonomi 


\section{PENDAHULUAN}

\section{Latar Belakang}

Pembangunan nasional memiliki tujuan yaitu mewujudkan kehidupan masyarakat adil dan makmur. Pembangunan nasional tidak terlepas dari pembangunan masing-masing daerah, yang merupakan bagian integral dalam upaya mencapai sasaran nasional. Pembangunan di setiap daerah, baik di kota maupun kabupaten berlangsung secara terusmenerus dan setiap daerah berusaha memajukan daerahnya sesuai dengan sumber daya alam, sumber daya manusia dan sumber daya lain yang dimiliki oleh setiap daerah.

Arsyad (2009), mengemukakan bahwa masalah pokok dalam pembangunan daerah adalah terletak pada penekanan terhadap kebijakan-kebijakan pembangunan yang didasarkan pada kekhasan daerah yang bersangkutan dengan menggunakan potensi sumber daya manusia, kelembagaan dan sumber daya fisik secara lokal (daerah). Proses pembangunan untuk menciptakan kesempatan kerja baru dan merangsang peningkatan kegiatan ekonomi. Pertumbuhan penduduk harus diimbangi dengan pertumbuhan kesempatan kerja, sehingga pertumbuhan penduduk tidak menjadi kendala dalam pembangunan ekonomi daerah. Laju pertumbuhan penduduk yang tinggi dan rendahnya kinerja pembangunan sumber daya manusia tidak memungkinkan penciptaan kesempatan kerja yang memadai dibandingkan dengan pertumbuhan angkatan kerja, sehingga dapat menyebabkan angka pengangguran meningkat. Pernyataan tersebut diperkuat oleh simanjuntak (1985), yang berpendapat bahwa jumlah penduduk dan angkatan kerja yang besar serta laju pertumbuhan penduduk yang tinggi sebenarnya tidak perlu menjadi masalah bila daya dukung ekonomi yang efektif di daerah itu cukup kuat dalam memenuhi berbagai macam kebutuhan masyarakat termasuk penyediaan kesempatan kerja.

Pembangunan daerah memerlukan tenaga kerja sebagai salah satu modal utama sebab tenaga kerja merupakan sumber daya dominan, baik dilihat dari segi kegiatan produksi maupun dari sisi pemanfaatan hasil-hasil pembangunan.
Tenaga kerja diharapkan mempunyai kualitas untuk menjamin tingkat produktivitas yang tinggi dan pekerja harus mendapatkan perlindungan yang memadai agar mereka memperoleh hak-haknya, baik sebagai pekerja maupun memenuhi peran sebagai anggota masyarakat. Jumlah penduduk yang semakin meningkat, berkaitan erat dengan jumlah angkatan kerja yang semakin meningkat pula. Jumlah lapangan kerja yang tidak seimbang dengan jumlah angkatan kerja menandakan bahwa pembangunan di suatu daerah belum berjalan secara efektif.

Kabupaten Minahasa Selatan merupakan Kabupaten di Sulawesi Utara. Kabupaten Minahasa Selatan memiliki luas wilayah $1.454,64 \mathrm{~km}^{2}$. Secara geografis Kabupaten Minahasa Selatan berada pada posisi strategis karena berada pada jalur lintas darat trans Sulawesi. Selain letak yang strategis Kabupaten Minahasa Selatan memiliki potensi sumber daya alam yang beragam. Kabupaten Minahasa Selatan memiliki kawasan perkebunan mencapai 70.891,86 Ha dengan komoditas utama kelapa dan cengkeh. Subsektor perkebunan menjadi penyumbang terbesar pada PDRB sektor pertanian. Selain itu, pesisir jalur laut bagian utara merupakan daerah yang strategis untuk pengembangan produksi perikanan di Kawasan Timur Indonesia. Subsektor perikanan merupakan penyumbang terbesar ke dua pada PDRB sektor pertanian. Kabupaten Minahasa Selatan juga memiliki kawasan pertambangan dan penggalian dengan komoditas emas, belerang, batu kapur dan batu pasir.

Kekuatan ekonomi Kabupaten Minahasa Selatan selain didukung oleh sumber daya alam, juga didukung dari segi sumber daya manusia. Oleh karena itu, SDM yang melimpah dan berkualitas merupakan investasi yang dapat mendorong pertumbuhan ekonomi suatu daerah. Tahun 2015 Kabupaten Minahasa Selatan memiliki penduduk sebanyak 204.983 jiwa. Jika dilihat berdasarkan kelompok umur, sebagian besar penduduk di Kabupaten Minahasa Selatan berada pada kelompok usia produktif yaitu 1564 tahun. Jumlah penduduk usia produktif ada sebanyak 136.528 jiwa dari jumlah penduduk keseluruhan. Jumlah ini merupakan suatu 
keuntungan yang sangat besar bagi keberhasilan pembangunan di Kabupaten Minahasa Selatan, mengingat penduduk produktif berpeluang lebih besar untuk bekerja dan menghasilkan pendapatan dibandingkan kelompok umur lainnya. Jika didukung dengan peningkatan kualitas pendidikan dan keterampilan, maka akan berdampak pada peningkatan produktivitas tenaga kerja dan peningkatan daya saing daerah.

Secara kuantitas distribusi tenaga kerja Kabupaten Minahasa Selatan yang bekerja menurut lapangan pekerjaan utama dibagi menjadi 3 sektor lapangan pekerjaan utama yaitu Sektor pertanian (pertanian, perkebunan, kehutanan, perburuan, dan perikanan), Sektor industri (pertambangan dan penggalian, industri pengolahan, listrik, gas, dan air minum serta konstruksi), dan Sektor jasa (perdagangan, rumah makan, dan jasa akomodasi, transportasi, perdagangan, dan komunikasi, lembaga keuangan, real estate, usaha persewaan, dan jasa perusahaan, jasa kemasyarakatan dan perorangan) dapat dilihat pada Tabel 1.

Tabel 1. Jumlah Tenaga Kerja Berdasarkan \begin{tabular}{llr} 
Lapangan & Pekerjaan & Utama \\
Kabupaten & Minahasa & Selatan \\
Tahun 2015 & & \\
\hline
\end{tabular}

\begin{tabular}{clc}
\hline No & $\begin{array}{c}\text { Lapangan } \\
\text { Pekerjaan Utama }\end{array}$ & $\begin{array}{c}\text { Tenaga Kerja } \\
\text { (Jiwa) }\end{array}$ \\
\hline 1 & Pertanian & 37.502 \\
2 & Industri & 33.347 \\
3 & Jasa & 18.962 \\
\hline & Jumlah/Total & 89.811 \\
\hline
\end{tabular}

Sumber: BPS Kabupaten Minahasa Selatan Tahun 2016

Berdasarkan pada tabel 1 dapat dilihat bahwa sektor pertanian dan sektor industri memberikan sumbangan paling besar dalam penciptaan lapangan pekerjaan di Kabupaten Minahasa Selatan. Sektor pertanian mampu menyerap tenaga kerja sebanyak 37.502 jiwa. Sektor selanjutnya yang mampu menyerap tenaga kerja terbanyak kedua adalah sektor industri yaitu sebanyak 33.347 jiwa.

\section{Rumusan Masalah}

Berdasarkan latar belakang yang telah diuraikan diatas maka yang menjadi permasalahan adalah:

1. Sektor manakah yang menjadi unggulan dalam penyerapan tenaga kerja di Kabupaten Minahasa Selatan.

2. Bagaimanakah kontribusi sektor unggulan dalam penyerapan tenaga kerja di Kabupaten Minahasa Selatan.

\section{Tujuan Penelitian}

Berdasarkan perumusan masalah yang dikemukakan, maka yang menjadi tujuan penelitian yaitu:

1. Untuk menganalisis sektor manakah yang menjadi unggulan dalam penyerapan tenaga kerja di Kabupaten Minahasa Selatan.

2. Untuk menganalisis kontribusi sektor unggulan dalam penyerapan tenaga kerja di Kabupaten Minahasa Selatan.

\section{Manfaat Penelitian}

Adapun manfaat penelitian ini diharapkan bisa memberikan informasi bagi pihak-pihak terkait tentang analisis sektor unggulan dalam penyerapan tenaga kerja di Kabupaten Minahasa Selatan.

\section{METODE PENELITIAN}

\section{Waktu dan Tempat Penelitian}

Penelitian ini dilaksanakan selama dua bulan dari bulan Januari sampai bulan Februari 2018 di Kabupaten Minahasa Selatan.

\section{Metode Pengumpulan Data}

Data yang digunakan dalam penelitian ini adalah data sekunder. Data sekunder yang diperoleh dari Badan Pusat Statistik Kabupaten Minahasa Selatan.

\section{Konsep Pengukuran Variabel}

Variabel yang diukur dalam penelitian ini yaitu :

1. Jumlah penduduk yang digunakan adalah jumlah penduduk Kabupaten Minahasa Selatan. 
2. Angkatan kerja Kabupaten Minahasa Selatan adalah bagian dari tenaga kerja yang sesungguhnya terlibat, atau berusaha untuk terlibat dalam kegiatan yang produktif, yaitu memproduksi barang dan jasa (Anonim, 1981 dalam Lolong, 2003).

3. Jumlah tenaga kerja berdasarkan tingkat pendidikan.

4. Jumlah tenaga kerja menurut lapangan pekerjaan utama.

\section{Sumber Data}

Analisis yang digunakan dalam penelitian ini adalah analisis location quotient (LQ). Location Quotient (LQ) adalah suatu perbandingan tentang besarnya peranan suatu sektor di suatu daerah terhadap besarnya peranan sektor tersebut secara nasional.

Selain itu, analisis LQ merupakan suatu pendekatan tidak langsung yang digunakan untuk mengukur kinerja basis ekonomi suatu daerah, artinya bahwa analisis ini digunakan untuk melakukan pengujian terhadap sektorsektor ekonomi yang termasuk dalam kategori sektor unggulan (Arsyad, 2010). berikut :

Untuk menghitung rumus LQ sebagai

$$
\mathrm{LQ}=\frac{v i / v t}{v i / v t}
$$

Keterangan :

LQ = Indeks Kuosien Lokasi.

vi = Jumlah tenaga kerja yang berada pada

sektor i di Kabupaten Minahasa Selatan.

vt $=$ Jumlah total tenaga kerja di Kabupaten

Minahasa Selatan.

$\mathrm{Vi}=$ Jumlah tenaga kerja yang berada pada

sektor i di Provinsi Sulawesi Utara.

$\mathrm{Vt}=$ Jumlah total tenaga kerja di Provinsi

Sulawesi Utara.

\section{HASIL DAN PEMBAHASAN}

\section{Kondisi Wilayah}

Kabupaten Minahasa Selatan adalah salah satu Kabupaten yang termasuk wilayah Provinsi Sulawesi Utara. Kabupaten Minahasa Selatan terletak pada koordinat antara $0^{\circ}, 47^{\prime}-1^{\circ} 24^{\prime}$ Lintang Utara dan $124^{\circ} 45^{\prime}$ Bujur Timur.
Ibukota Kabupaten Minahasa Selatan adalah Kota Amurang. Kabupaten Minahasa Selatan terbentuk berdasarkan Undang-Undang Nomor 10 Tahun 2003 tentang pembentukan Kabupaten Minahasa Selatan dan Kota Tomohon di Provinsi Sulawesi Utara. Luas Kabupaten Minahasa Selatan adalah 1.484,47 $\mathrm{km}^{2}$ terdiri dari 17 Kecamatan dengan 177 Desa.

Berdasarkan posisi geografisnya Kabupaten Minahasa Selatan memiliki batasbatas wilayah sebagai berikut:

1) Sebelah Utara: Berbatasan dengan Kabupaten Minahasa.

2) Sebelah Timur: Berbatasan dengan Kabupaten Minahasa Tenggara.

3) Sebelah Selatan: Berbatasan dengan Kabupaten Bolang Mongondow.

4) Sebelah Barat: Berbatasan dengan Laut Sulawesi Utara.

\section{Kependudukan}

Masalah kependudukan meliputi jumlah, komposisi dan distribusi penduduk. Jumlah penduduk yang besar dapat menjadi modal pembangunan kualitasnya baik, namun sebaliknya dapat menjadi beban pembangunan bila kualitasnya rendah. Kualitas penduduk dapat ditingkatkan dengan peningkatan kebutuhan pangan, sandang, papan, dan pendidikan, kesehatan yang layak seiring dengan peningkatan jumlah penduduk.

Rencana pembangunan perlu ditunjang dengan data jumlah penduduk, persebaran dan susunannya menurut kelompok umur penduduk yang relefan dengan rencana tersebut. Oleh sebab itu untuk menunjang keberhasilan pembangunan nasional, dalam menangani permasalah penduduk, pemerintah tidak saja mengarahkan pada upaya pengendalian jumlah penduduk tapi juga menitik beratkan pada peningkatan kualitas sumber daya manusiannya.

\section{Jumlah dan Pertumbuhan Penduduk}

Penduduk merupakan salah satu faktor penting dalam kegiatan ekonomi dan pembangunan perekonomian di suatu daerah, karena selain sebagai pelaku pembangunan jug sebagai objek pembangunan. Namun, jumlah penduduk yang besar menjadi masalah utama 
dan tidak mudah untuk diatasi. Penduduk Kabupaten Minahasa Selatan selalu bertambah setiap tahunnya. Sehingga pertambahan penduduk berpengaruh pada jumlah tenaga kerja yang tercipta. Dari Tabel 2 dapat diketahui jumlah penduduk Kabupaten Minahasa Selatan adalah sebagai berikut.

Tabel 2. Jumlah dan Pertumbuhan Penduduk Kabupaten Minahasa Selatan Tahun 2010-2015

\begin{tabular}{ccc}
\hline Tahun & $\begin{array}{c}\text { Jumlah } \\
\text { Penduduk (Jiwa) }\end{array}$ & $\begin{array}{c}\text { Pertumbuhan } \\
(\%)\end{array}$ \\
\hline 2010 & 195.373 & 1,40 \\
2011 & 198.109 & 0,89 \\
2012 & 199.875 & 0,90 \\
2013 & 201.668 & 0,82 \\
2014 & 203.317 & 0,82 \\
2015 & 204.983 & 0,79 \\
\hline Sumber: BPS & Kabupaten Minahasa & Selatan Tahun \\
2016 & &
\end{tabular}

Berdasarkan pada Tabel 2 dapat diketahui bahwa jumlah penduduk Kabupaten Minahasa Selatan terus mengalami peningkatan. Jumlah penduduk Kabupaten Minahasa Selatan mengalami peningkatan sebanyak 1.666 jiwa dibandingkan dengan tahun 2014. Sedangkan jika dibandingkan dengan tahun 2010, jumlah penduduk Kabupaten Minahasa Selatan meningkat sebanyak 9.430 jiwa. Semenjak tahun 2010-2015 secara absolut jumlah penduduk terus bertambah namun pertumbuhannya relatif mengalami penurunan. Penurunan pertumbuhan penduduk mengindikasikan keberhasilan program keluarga berencana dimana program ini ditujukan untuk menekan angka kelahiran, menciptakan norma keluarga kecil sehingga terbuka peluang bagi suatu keluarga untuk meningkatkan kualitas keluarganya.

Tahun 2015 Kabupaten Minahasa Selatan menempati peringkat 5 dengan jumlah penduduk terbanyak di Provinsi Sulawesi Utara. Jumlah penduduk Kabupaten Minahasa Selatan sebanyak 204.983 jiwa. Kabupaten/Kota dengan jumlah penduduk terbanyak di Provinsi Sulawesi Utara adalah Kota Manado yang juga merupakan Ibukota Sulawesi Utara dengan jumlah penduduk sebanyak 425.634 jiwa. Dengan jumlah penduduk yang relatif besar, permasalahan kependudukan di Kabupaten
Minahasa Selatan perlu mendapat perhatian yang serius. Oleh karena itu, upaya mengendalikan pertumbuhan penduduk disertai dengan peningkatan kesejahteraan penduduk harus dilaksanakan.

\section{Ketenagakerjaan}

Salah satu masalah besar yang menjadi perhatian pemerintah adalah permasalahan di bidang ketenagakerjaan. Masalah ketenagakerjaan merupakan masalah yang sangat sensitif yang harus diselesaikan dengan berbagai pendekatan agar masalah tersebut tidak meluas yang berdampak pada penurunan kesejahteraan dan keamanan masyarakat. Tingginya tingkat pengangguran, rendahnya perluasan kesempatan kerja yang terbuka, rendahnya kompetensi dan produktivitas tenaga kerja merupakan sebagian kecil masalah yang dihadapi oleh pemerintah.

\section{Tingkat Partisipasi Angkatan Kerja dan Tingkat Pengangguran Terbuka}

Tingkat Partisipasi Angkatan Kerja (TPAK) dan Tingkat Pengangguran Terbuka (TPT) merupakan indikator ketenagakerjaan yang penting digunakan untuk menganalisa dan mengukur capaian hasil pembangunan. TPAK digunakan untuk mengukur besarnya jumlah angkatan kerja, indikator ini merupakan rasio antara jumlah angkatan kerja dengan jumlah penduduk usia kerja (usia produktif 15 tahun ke atas). Selain TPAK, dalam analisis angkatan kerja juga dikenal indikator yang biasa digunakan untuk mengukur pengangguran yaitu TPT. Pengangguran terbuka didefinisikan sebagai orang yang sedang mencari pekerjaan atau yang sedang mempersiapkan usaha atau juga yang tidak mencari pekerjaan karena merasa tidak mungkin lagi mendapatkan pekerjaan, termasuk juga mereka yang baru mendapat kerja tetapi belum mulai bekerja. Pengangguran terbuka tidak termasuk orang yang masih sekolah atau mengurus rumah tangga, sehingga hanya orang yang termasuk angkatan kerja saja yang merupakan pengangguran terbuka. TPT dapat mencerminkan besarnya jumlah penduduk dalam karegori angkatan kerja yang termasuk dalam pengangguran. Dari Tabel 3 dapat 
diketahui tingkat partisipasi angkatan kerja dan tingkat pengangguran terbuka Kabupaten Minahasa Selatan adalah sebagai berikut.

Tabel 3. Tingkat Partisipasi Angkatan Kerja dan Tingkat Pengangguran Terbuka Kabupaten Minahasa Selatan Tahun 2013-2015

\begin{tabular}{|c|c|c|c|}
\hline \multirow[b]{2}{*}{ Kegiatan Utama } & \multicolumn{3}{|c|}{ Tahun } \\
\hline & 2013 & 2014 & 2015 \\
\hline Angkatan Kerja (Jiwa) & 90.163 & 95.445 & 96.420 \\
\hline 1. Bekerja (Jiwa) & 84.133 & 90.355 & 89.811 \\
\hline 2. Pengangguran (Jiwa) & 6.030 & 5.090 & 6.609 \\
\hline Bukan Angkatan Kerja (Jiwa) & 58.510 & 54.902 & 55.797 \\
\hline Jumlah/Total (Jiwa) & 148.673 & 150.347 & 152.217 \\
\hline TPAK (\%) & 60,65 & 63,48 & 63,34 \\
\hline TPT $(\%)$ & 6,69 & 5,33 & 6,85 \\
\hline
\end{tabular}

Sumber: Data BPS Kabupaten Minahasa Selatan 2016

Berdasarkan pada Tabel 3 dapat diketahui bahwa TPT Kabupaten Minahasa Selatan mengalami kenaikan dalam 3 tahun terakhir. TPT Tahun 2013 sebesar 6,69\% dan pada tahun 2015 meningkat menjadi $6,85 \%$. Sejalan dengan TPT, TPAK juga mengalami kenaikan, dari 60,65\% di tahun 2013 menjadi 63,34\% pada tahun 2015. Penambahan angkatan kerja yang dibarengi dengan bertambahnya pengangguran mengindikasikan masih kurangnya lapangan kerja di Kabupaten Minahasa Selatan yang dapat menarik para pengangguran masuk ke dalamnya.

\section{Tingkat Pendidikan}

Setiap orang selalu berharap dirinya akan mudah mendapatkan pekerjaan layak yang sesuai dengan keahlian yang dia miliki serta tingkat pendidikan yang ditamatkan. Semakin tinggi tingkat pendidikan seseorang akan berdampak pada semakin tinggi pula harapan dan kesempatan untuk mendapatkan pekerjaan yang sesuai dengan tingkat pendidikannya. Namun, keterbatasan lapangan kerja yang tersedia bagi mereka yang mempunyai ijazah tinggi menyebabkan mereka tidak terserap pada lapangan pekerjaan tersebut. Sebagian besar dari mereka yang merupakan lulusan pendidikan tinggi enggan menerima pekerjaan yang tidak sesuai dengan jenis keahlian dan jenjang pendidikan yang telah ditamatkan. Sebagian besar dari mereka yang tidak mendapatkan pekerjaan menjadi penganggur.
Dari Tabel 4 dapat diketahui tenaga kerja Kabupaten Minahasa Selatan menurut tingkat pendidikan yang ditamatkan adalah sebagai berikut.

Tabel 4. Tenaga Kerja Kabupaten Minahasa Selatan Menurut Tingkat Pendidikan yang Ditamatkan Tahun 2010-2015 (Jiwa)

\begin{tabular}{lcccccc}
\hline \multirow{2}{*}{ Pendidikan } & \multicolumn{6}{c}{ Tahun } \\
\cline { 2 - 7 } & 2010 & 2011 & 2012 & 2013 & 2014 & 2015 \\
\hline Tidak Pemah Sekolah & 249 & 443 & - & 397 & 148 & - \\
Tidak Tamat SD & 19.288 & 13.648 & 10.302 & 11.574 & 9.189 & 11.876 \\
SD & 21.338 & 25.476 & 25.092 & 23.980 & 29.470 & 25.597 \\
SMP & 23.049 & 21.830 & 21.971 & 18.934 & 24.220 & 23.173 \\
SMA & 25.187 & 25.248 & 27.101 & 28.225 & 26.491 & 29.852 \\
Sarjana & 7.851 & 6.576 & 5.612 & 7.053 & 5.927 & 5.922 \\
\hline Jumlah/Total & 96.962 & 93.221 & 90.078 & 90.163 & 95.445 & 96.420
\end{tabular}

Sumber : Data BPS Kabupaten Minahasa Selatan 2016

Berdasarkan pada Tabel 4 dapat diketahui bahwa selama tahun 2010-2015 tenaga kerja Kabupaten Minahasa Selatan menurut tingkat pendidikan yang ditamatkan didominasi oleh tenaga kerja yang lulusan SMA. Pertumbuhan tenaga kerja lulusan SMA cenderung mengalami peningkatan dalam 5 tahun terakhir. Tahun 2010 sebanyak 25.187 jiwa, tahun 2011 meningkat menjadi 25.248 jiwa, tahun 2012 meningkat menjadi 27.101 jiwa, tahun 2013 meningkat menjadi 28.225 jiwa, dan tahun 2015 meningkat menjadi 29.852 jiwa. Tenaga Kerja dengan lulusan sarjana hanya berada pada posisi kelima. Pertumbuhan tenaga kerja lulusan sarjana cenderung mengalami penurunan dalam 5 tahun terakhir. Tahun 2010 sebanyak 7.851 jiwa, tahun 2011 menurun menjadi 6.576 jiwa, tahun 2012 menurun menjadi 5.612 jiwa, tahun 2013 tenaga kerja lulusan sarjana meningkat menjadi 7.053 jiwa, tahun 2014 kembali menurun menjadi 5.927 jiwa, dan tahun 2015 menurun menjadi 5.922 jiwa. Masih kurangnya tenaga kerja dengan lulusan sarjana disebabkan oleh kurangnya kesadaran penduduk Kabupaten Minahasa Selatan akan pentingnya mengenal pendidikan, karena produktivitas tenaga kerja ditentukan oleh latar belakang pendidikan dari penduduk itu sendiri. Dimana semakin tinggi pendidikan yang dicapai maka produktivitas tenaga kerja akan semakin bertambah. 


\section{Kesempatan Kerja}

Kesempatan kerja adalah suatu keadaan yang menggambarkan ketersediaan pekerjaan untuk diisi oleh para pencari kerja. Dapat juga didefinisikan sebagai jumlah penduduk yang digunakan dalam suatu kegiatan ekonomi untuk memproduksi barang dan jasa. Dalam penelitian ini, kesempatan kerja didekati dengan jumlah tenaga kerja yang bekerja menurut lapangan pekerjaan uatama, sehingga dari data jumlah tenaga kerja yang bekerja menurut lapangan pekerjaan utama tersebut dapat diketahui kesempatan kerja dari tiap sektor perekonomian/lapangan pekerjaan utama yang ada di Kabupaten Minahasa Selatan. Tiap lapangan pekerjaan utama memiliki kemampuan yang berbeda dalam menyerap tenaga kerja. Sektor yang mempekerjakan lebih banyak tenaga kerja umumnya menghasilkan barang dan jasa dalam jumlah yang lebih banyak juga. Tenaga kerja yang bekerja menurut lapangan pekerjaan utama di Kabupaten Minahasa Selatan dibagi menjadi sembilan sektor yaitu sektor pertanian, sektor pertambangan dan penggalian, sektor listrik, gas, dan air minum, sektor konstruksi, sektor perdagangan, rumah makan dan jasa akomodasi, sektor transportasi, pergudangan, dan komunikasi, sektor lembaga keuangan, real estate, usaha persewaan, dan jasa perusahaan, sektor jasa kemasyarakatan, sosial, dan perorangan. Dari Tabel 5 dapat diketahui jumlah tenaga kerja Kabupaten Minahasa Selatan yang bekerja menurut lapangan pekerjaan utama adalah sebagai berikut.

\begin{tabular}{|c|c|c|c|c|c|c|}
\hline \multirow{3}{*}{ No } & \multicolumn{6}{|c|}{ Menurut Lapangan Pekerjaan Tahun 2010-2014 (Jiwa) } \\
\hline & \multirow{2}{*}{ Lapangan Pekerjaan } & \multicolumn{5}{|c|}{ Tahun } \\
\hline & & 2010 & 2011 & 2012 & 2013 & 2014 \\
\hline 1 & Pertanian & 45.552 & 29.695 & 40.613 & 34.814 & 33.302 \\
\hline 2 & $\begin{array}{l}\text { Pertambangan dan } \\
\text { Penggalian }\end{array}$ & 325 & 1.235 & 1.747 & 2.444 & 295 \\
\hline 3 & Industri Pengolahan & 6.921 & 15.899 & 8.778 & 11.564 & 17.666 \\
\hline 4 & $\begin{array}{l}\text { Listrik, Gas dan Air } \\
\text { Minum }\end{array}$ & 326 & 1.092 & 63 & 568 & 655 \\
\hline 5 & Konstruksi & 4.073 & 8.340 & 4.753 & 7.300 & 5.446 \\
\hline 6 & $\begin{array}{l}\text { Perdagangan, Rumah } \\
\text { Makan, dan Jasa } \\
\text { Akomodasi }\end{array}$ & 13.794 & 13.499 & 11.744 & 19.104 & 15.005 \\
\hline 7 & $\begin{array}{l}\text { Transportasi, } \\
\text { Pergudangan, dan } \\
\text { Komunikasi }\end{array}$ & 5.744 & 5.454 & 5.025 & 3.377 & 5.806 \\
\hline 8 & $\begin{array}{l}\text { Lembaga Keuangan, } \\
\text { Real Estate, Usaha } \\
\text { Persewaan dan Jasa } \\
\text { Perusahaan }\end{array}$ & 275 & 209 & 1.048 & 910 & 1.813 \\
\hline 9 & $\begin{array}{l}\text { Jasa Kemasyarakatan, } \\
\text { Sosial dan Perorangan }\end{array}$ & 12.785 & 12.082 & 9.517 & 11.052 & 10.367 \\
\hline & Jumlah/Total & 89.795 & 87.505 & 83.288 & 84.133 & 90.355 \\
\hline
\end{tabular}

Berdasarkan pada Tabel 5 dapat diketahui bahwa sektor pertanian mendominasi dalam penyerapan tenaga kerja di Kabupaten Minahasa Selatan tahun 20102014, walaupun pertumbuhanya cenderung menurun. Sektor pertanian menyerap tenaga kerja terbesar yaitu pada tahun 2010 sebesar 45.552 jiwa, sedangkan terendah yatiu pada tahun 2011 sebesar 29.695 jiwa. Sektor lain yang memiliki kesempatan kerja tinggi yaitu sektor industri pengolahan. Sektor industri pengolahan menyerap tenaga kerja terbesar pada tahun 2014 sebesar 17.666 jiwa, sedangkan terendah yaitu pada tahun 2010 sebesar 6.921 jiwa. Pertumbuhan sektor industri pengolahan mengalami peningkatan dalam lima tahun terakhir. Peningkatan ini terjadi karena beralihnya penduduk yang sebelumnya bekerja pada sektor pertanian ke sektor industri pengolahan yang diharapkan dapat memberikan pendapatan yang lebih karena tidak tergantung musim. Hal ini dapat dilihat dengan menurunya sektor pertanian dalam penyerapan tenaga kerja tahun 20102015, sedangkan pada tahun tersebut sektor industri pengolahan mengalami peningkatan dalam penyerapan tenaga kerja.

Kabupaten Minahasa Selatan merupakan wilayah dengan potensi sumber daya alam yang melimpah. Kabupaten Minahasa Selatan memiliki kawasan perkebunan dengan luas 70.891,86 Ha. Perkebunan menjadi penyumbang terbesar pada PDRB sektor pertanian. Hampir 70 persen penduduk Kabupaten Minahasa Selatan menggantungkan hidup pada komoditi perkebunan meliputi tanaman kelapa, cengkih, aren, kakao, pala, dan lainnya. Sub sektor perkebunan merupakan salah satu penggerak perekonomian di Kabupaten Minahasa Selatan yang dapat diandalkan dalam memperkokoh fundamental perekonomian daerah, sebagai pemasok terbesar bahan baku industri. Selain itu, pesisir jalur laut bagian utara merupakan daerah yang strategis untuk pengembangan produksi perikanan di Kawasan Timur Indonesia. Subsektor perikanan merupakan 
penyumbang terbesar kedua pada PDRB sektor pertanian.

Sektor industri di Kabupaten Minahasa Selatan didominasi oleh subsektor industri pengolahan. Pada subsektor indutri pengolahan di Kabupaten Minahasa Selatan didominasi oleh industri makanan, sebanyak 5.765 jiwa, dimana 12 usaha diantaranya merupakan usaha dengan skala menengah hingga besar. Industri makanan di Kabupaten Minahasa Selatan banyak memanfaatkan hasil sumber daya alam yang meliputi hasil pertanian, perkebunan, dan perikanan. Potensi alam Kabupaten Minahasa Selatan berkontribusi bagi berkembangnya perindustrian di Minahasa Selatan. Buah kelapa yang melimpah membuka peluang beberapa perusahaan, seperti PT.Cargill Indonesia menanamkan investasinya untuk pembuatan Crude Coconut Oil. Selain itu, potensi perikanan di wilayah Kabupaten Minahasa Selatan juga telah menarik para investor untuk mendirikan industri-industri perikanan seperti PT.Ninchindo Manado Suisan dan CV.Sakura Ria.

\section{Analisis Location Quotient (LQ)}

Sektor unggulan adalah satu atau beberapa sektor yang mempunyai keunggulan komparatif dibandingkan dengan beberapa sektor lain yang tedapat dalam suatu daerah. Untuk itu dalam suatu perencanaan pembangunan ekonomi regional, suatu sektor unggulan harus mendapat perhatian untuk dikembangkan lebih lanjut, khususnya untuk kepentingan daerah dan untuk suksesnya pembangunan nasional pada umumnya. Untuk mengetahui kelompok sektor unggulan yang terdapat pada suatu daerah digunakan analisis Location Quotient (LQ). Hasil LQ suatu sektor lebih dari 1 menunjukkan bahwa sektor tersebut mempunyai keunggulan komparatif dari sektor lain, sebaliknya bila nilai LQ lebih kecil dari 1 menunjukkan bahwa sektor tersebut tidak mempunyai keunggulan komparatif dan kurang potensial untuk dikembangkan. Dari tabel 6 dapat diketahui nilai LQ tenaga kerja Kabupaten Minahasa Selatan yang bekerja menurut lapangan pekerjaan utama adalah sebagai berikut.
Tabel 6. Perhitungan LQ Tenaga Kerja Kabupaten Minahasa Selatan yang Bekerja Menurut Lapangan Pekerjaan Utama Tahun 2010-2014

\begin{tabular}{|c|c|c|c|c|c|c|}
\hline \multirow{2}{*}{ Lapangan Pekerjaan Utama } & \multicolumn{5}{|c|}{ LQ } & \multirow{2}{*}{$\begin{array}{l}\text { Rata-Rata } \\
\text { LQ }\end{array}$} \\
\hline & 2010 & 2011 & 2012 & 2013 & 2014 & \\
\hline Pertanian & 1,32 & 1,04 & 1,49 & 1,19 & 1,12 & 1,23 \\
\hline Pertambangan dan Penggalian & 0,19 & 0,56 & 0,66 & 1,19 & 0,15 & 0,55 \\
\hline Industri Pengolahan & 1,42 & 2,72 & 1,74 & 2.54 & 2.68 & 2,22 \\
\hline Listrik, Gas dan Air & 0,74 & 2.65 & 0,19 & 1,88 & 2.06 & 1,50 \\
\hline Konstruksi & 0,71 & 1,14 & 0,71 & 1,12 & 0,74 & 0,88 \\
\hline $\begin{array}{l}\text { Perdagangan, Rumah Makan dan } \\
\text { Jasa Akomodasi }\end{array}$ & 0,83 & 0,77 & 0,71 & 1,14 & 0,83 & 0,85 \\
\hline $\begin{array}{l}\text { Transportasi, Pergudangan, dan } \\
\text { Komunikasi }\end{array}$ & 0,76 & 0,84 & 0,30 & 0,53 & 0,79 & 0,64 \\
\hline $\begin{array}{l}\text { Lembaga Keuangan, Real Estate, } \\
\text { Usaha Persewaan dan Jasa } \\
\text { Perusahaan }\end{array}$ & 0,19 & 0,10 & 0,48 & 0,33 & 0,66 & 0,35 \\
\hline $\begin{array}{l}\text { Jasa Kemasyarakatan, Sosial dan } \\
\text { Perorangan }\end{array}$ & 0,73 & 0,68 & 0,59 & 0,68 & 0,62 & 0,66 \\
\hline
\end{tabular}

Berdasarkan pada Tabel 6 dapat diketahui bahwa dengan perhitungan LQ tahun 20102015 di Kabupaten Minahasa Selatan terdapat 3 sektor unggulan yaitu sektor pertanian, sektor industri pengolahan, dan sektor listrik, gas, dan air minum. Sektor unggulan pertama adalah sektor industri pengolahan dengan nilai rata-rata LQ sebesar 2,22. Pertumbuhan sektor industri pengolahan cenderung mengalami peningkatan pada tahun 2010-2014. Tahun 2010 nilai LQ sebesar 1,42, tahun 2011 meningkat menjadi 2,72, tahun 2012 sempat menurun menjadi 1,74, tahun 2013 kembali meningkat menjadi 2,54, dan tahun 2015 meningkat menjadi 2,68. Sektor unggulan kedua adalah sektor listrik, gas, dan air minum dengan nilai rata-rata LQ sebesar 1,50. Pertumbuhan sektor listrik, gas, dan air minum cenderung mengalami peningkatan pada tahun 2010-2014. Tahun 2010 nilai LQ sebesar 0,74, tahun 2011 meningkat menjadi 2,65, tahun 2012 sempat menurun menjadi 0,19 , tahun 2013 kembali meningkat menjadi 1,88, dan tahun 2014 meningkat menjadi 2,06. Sektor unggulan ketiga adalah sektor pertanian dengan nilai rata-rata LQ sebesar 1,23. Pertumbuhan sektor pertanian cenderung mengalami penurunan pada tahun 2010-2015. Tahun 2010 nilai LQ sebesar 1,32, tahun 2011 menurun menjadi 1,04, tahun 2012 sempat meningkat menjadi 1,49, tahun 2013 kembali menurun sebesar 1,19, dan tahun 2014 menurun menjadi 1,12. Ketiga sektor ini menjadi unggulan karena memiliki nilai LQ lebih dari 1 (LQ > 1) Artinya sektor pertanian, sektor industri, dan sektor listrik, gas, dan air minum di Kabupaten Minahasa Selatan lebih dominan 
dalam penyerapan tenaga kerja dibandingkan sektor yang sama di Provinsi Sulawesi Utara.

\section{Kontribusi Sektor Unggulan Dalam Penyerapan Tenaga Kerja}

Berdasarkan hasil penelitian yang diperoleh dengan mengunakan metode LQ maka yang menjadi sektor unggulan dalam penyerapan tenaga kerja adalah sektor industri pengolahan, sektor listrik, gas, dan air minum, dan sektor pertanian. Dari Tabel 7 dapat diketahui kontribusi sektor unggulan dalam penyerapan tenaga kerja di Kabupaten Minahasa Selatan adalah sebagai berikut.

\begin{tabular}{|c|c|c|c|c|c|}
\hline \multirow{2}{*}{ Sektor Unggulan } & \multicolumn{5}{|c|}{ Tahun } \\
\hline & 2010 & 2011 & 2012 & 2013 & 2014 \\
\hline Pertanian (\%) & 51,88 & 33,93 & 48,76 & 41,38 & 36,85 \\
\hline Industri Pengolahan (\%) & 7,88 & 18,16 & 10,53 & 13,74 & 19,55 \\
\hline Listrik, Gas, dan Air Minum(\%) & 0,37 & 1,24 & 0,07 & 0,67 & 0,72 \\
\hline
\end{tabular}

Berdasarkan pada Tabel 7 dapat diketahui bahwa sektor pertanian berkontribusi paling besar dalam penyerapan tenaga kerja di Kabupaten Minahasa Selatan. Namun kontribusinya cenderung mengalami penurunan pada tahun 2010-2014. Kontribus sektor pertanian tahun 2010 sebesar $51,88 \%$, tahun 2011 menurun menjadi 33,93\%, tahun 2012 sempat meningkat menjadi $48.76 \%$, tahun 2013 kembali menurun menjadi $41,38 \%$, dan tahun 2014 menurun menjadi 36,85\%. Sektor kedua yang berkontribusi paling besar adalah sektor industri pengolahan. Kontribusi sektor industri pengolahan cenderung mengalami peningkatan pada tahun 2010-2014. Kontribusi sektor industri tahun 2010 sebesar 7,88\%, tahun 2011 meningkat menjadi $18,16 \%$, tahun 2012 sempat menurun menjadi 10,53\%, tahun 2013 kembali meningkat menjadi 13,74\%, dan tahun 2014 meningkat menjadi $19,55 \%$. Sedangkan sektor yang berkontribusi paling kecil adalah sektor listrik, gas, dan air minum. Kontribusi sektor listrik, gas dan air minum mengalami peningkatan pada tahun 2010-2014. Kontribusinya tahun 2010 sebesar $0,37 \%$, tahun 2011 meningkat menjadi 1,24\%, tahun 2012 sempat menurun menjadi $0,07 \%$, tahun 2013 kembali meningkat menjadi $0,67 \%$, dan tahun
2014 meningkat menjadi $0,72 \%$. Peningkatan kontribusi sektor industri dan sektor listrikm, gas, dan air minum disebabkan oleh menurunya kontribusi sektor pertanian pada tahun 2010-2014. Penurunan pada sektor pertanian disebabkan oleh mulai beralihnya penduduk yang bekerja pada sektor pertanian ke sektor industi pengolahan dan sektor listrik, gas dan air minum karena ingin mendapatkan pendapatan yang lebih karena tidak tergantung musim.

\section{KESIMPULAN DAN SARAN}

\section{Kesimpulan}

Berdasarkan hasil penelitian kontribusi sektor pertanian paling besar dalam penyerapan tenaga kerja di Kabupaten Minahasa Selatan. Namun kontribusinya pada tahun 2010-2014 cenderung mengalami penurunan. Sektor industri pengolahan kontribusinya paling besar kedua dalam penyerapan tenaga kerja di Kabupaten Minahasa Selatan. Kontribusinya cenderung mengalami peningkatan pada tahun 2010-2014. Sedangkan sektor listrik, gas, dan air minum kontribusinya paling sedikit dalam penyerapan tenaga kerja di Kabupaten Minahasa Selatan. Namun Kontribusnya cenderung mengalami peningkatan pada tahun 2010-2014, dengan menggunakan analisis Location Quotient (LQ) yang menjadi sektor unggulan adalah sektor pertanian, sektor industri pengolahan, dan sektor listrik, gas, dan air minum. Sektor pertanian, sektor industri pengolahan, dan sektor listrik, gas, dan air minum menjadi sektor unggulan karena memiliki nilai LQ lebih dari 1 (LQ > 1). Artinya ketiga sektor ini di Kabupaten Minahasa Selatan lebih dominan dalam penyerapan tenaga kerja dari pada sektor yang sama di Provinsi Sulawesi Utara.

\section{Saran}

Diperlukan adanya perhatian dari pemerintah terhadap perkembangan sektor unggulan sehingga dapat memberikan kontribusi terhadap penyerapan tenaga kerja di Kabupaten Minahasa Selatan. 


\section{DAFTAR PUSTAKA}

Arsyad, L. 2009. Pengantar Perencanaan dan Pembangunan Ekonomi Daerah Edisi Kedua Cetakan Pertama. BPFE UGM. Yogyakarta.

Arsyad, L. 2010. Ekonomi pembangunan Edisi ke 5. Penerbit : UPP STIM YKPN, Yogyakarta.

Lolong, J. L. 2003. Proyeksi Penyerapan Tenaga Kerja Di Provinsi Sulawesi Utara. Skripsi Fakultas Pertanian Universitas Sam Ratulangi, Manado.

Simanjuntak, P. J. 1985. Pengantar Ekonomi Sumber Daya Manusia. Jakarta: Fakultas Ekonomi Universitas Indonesia. 